\title{
Consumer acceptability and market potential of developed diversified products from cotton rags and waste papers
}

\author{
REENA ROY AND SUDHA BABEL
}

Received: 06.06.2016; Revised: 02.11.2016; Accepted: 12.11.2016

See end of the paper for authors' affiliations

\section{REENA ROY}

Department of Textiles and Apparel Designing, College of Home Science, Maharana Pratap University of Agriculture and Technology, UDAIPUR (RAJASTHAN) INDIA
ABSTRACT : Cotton fibre is a natural seed hair fibre. Discarded textiles and clothing are in strong demand from markets for reuse and recycling across the world. From these raw mixed rags, a new product can be created. Present study was carried out in three stages. The first stage included to design and develops diversified products from cotton rags and waste papers, second stage was to study the consumer acceptability and third stage was to find out market potential of developed products. The study was carried out in Udaipur City. Background information was collected from 30 house wives and 30 market personnel. Then the preference of respondents regarding diversified products from cotton rags and waste papers was taken. Total 13 products were developed, these were basket, photo frame. Flower pot, pen stand, dipak, tray, quotation holder, ash tray, bowl, tea coaster, wall hanging, paper weight and bandharwall using cotton rags and waste papers. In second stage the assessment of consumer acceptability and market potential of developed diversified products was made by 30 sample house wife and 30 sample market personnel's. A 5 point rating scale performa was administered on 60 respondents for this purpose. Finding of the study revealed that developed products were highly appreciated by all the respondents. Of the products the most preferred was flower pot with first rank followed by basket photo frame. Rest products also got good scores. Acceptance percentage of all products ranged between 62 per cent to more than 80 per cent. Cost of all products ranged between Rs. 20 to Rs. 70 .

KEY WORDS: Cotton rags, Waste papers, Diversified products, Consumer acceptability, Market potential, Employment generation

- HOW TO CITE THIS PAPER : Roy, Reena and Babel, Sudha (2016). Consumer acceptability and market potential of developed diversified products from cotton rags and waste papers. Asian J. Home Sci., 11 (2) : 410-414, DOI: 10.15740/HAS/AJHS/11.2/410-414. 